\title{
Short course radiotherapy with simultaneous integrated boost for stage I-II breast cancer, early toxicities of a randomized clinical trial
}

Hilde Van Parijs ${ }^{1 *}$, Geertje Miedema ${ }^{1}$, Vincent Vinh-Hung ${ }^{1}$, Sylvia Verbanck ${ }^{2}$, Nele Adriaenssens ${ }^{3}$, Dirk Kerkhove ${ }^{4}$, Truus Reynders ${ }^{1}$, Daniel Schuermans ${ }^{2}$, Katrien Leysen', Shane Hanon², Guy Van Camp ${ }^{4}$, Walter Vincken², Guy Storme ${ }^{1}$, Dirk Verellen ${ }^{1}$ and Mark De Ridder ${ }^{1}$

\begin{abstract}
Background: TomoBreast is a unicenter, non-blinded randomized trial comparing conventional radiotherapy (CR) vs. hypofractionated Tomotherapy (TT) for post-operative treatment of breast cancer. The purpose of the trial is to compare whether $\Pi$ can reduce heart and pulmonary toxicity. We evaluate early toxicities.

Methods: The trial started inclusion in May 2007 and reached its recruitment in August 2011. Women with stage T1-3NOMO or T1-2N1M0 breast cancer completely resected by tumorectomy (BCS) or by mastectomy (MA) who consented to participate were randomized, according to a prescribed computer-generated randomization schedule, between control arm of CR 25x2 Gy/5 weeks by tangential fields on breast/chest wall, plus supraclavicular-axillary field if node-positive, and sequential boost 8x2 Gy/2 weeks if BCS (cumulative dose 66 Gy/7 weeks), versus experimental $\Pi \mathrm{arm}$ of $15 \times 2.8 \mathrm{~Gy} / 3$ weeks, including nodal areas if node-positive and simultaneous integrated boost of $0.6 \mathrm{~Gy}$ if BCS (cumulative dose $51 \mathrm{~Gy} / 3$ weeks). Outcomes evaluated were the pulmonary and heart function. Comparison of proportions used one-sided Fisher's exact test.

Results: By May 2010, 70 patients were randomized and had more than 1 year of follow-up. Out of 69 evaluable cases, 32 were assigned to CR (21 BCS, $11 \mathrm{MA}), 37$ to $\Pi$ ( $20 \mathrm{BCS}, 17 \mathrm{MA})$. Skin toxicity of grade $\geq 1$ at 2 years was $60 \%$ in CR, vs. $30 \%$ in $\Pi \mathrm{arm}$. Heart function showed no significant difference for left ventricular ejection fraction at 2 years, CR $4.8 \%$ vs. $T$ 4.6\%. Pulmonary function tests at 2 years showed grade $\geq 1$ decline of FEV1 in $21 \%$ of CR, vs. $15 \%$ of $T$ and decline of DLCo in $29 \%$ of $C R$, vs. $7 \%$ of $T(P=0.05)$.

Conclusions: There were no unexpected severe toxicities. Short course radiotherapy of the breast with simultaneous integrated boost over 3 weeks proved feasible without excess toxicities. Pulmonary tests showed a slight trend in favor of Tomotherapy, which will need confirmation with longer follow-up of patients.
\end{abstract}

Trail registration: ClinicalTrials.gov NCT00459628

Keywords: Early breast cancer, Hypofractionation, Simultaneous integrated boost (SIB), Image guided radiation treatment (IGRT), Intensity modulated radiotherapy (IMRT)

\footnotetext{
* Correspondence: hilde.vanparijs@uzbrussel.be

'Department of Radiotherapy, UZ Brussel, Laarbeeklaan 101, 1090 Brussels, Belgium

Full list of author information is available at the end of the article
} 


\section{Background}

Breast cancer is the most frequently diagnosed cancer and the leading cause of cancer death in women, accounting worldwide for $23 \%$ of total new cancer cases and $14 \%$ of total cancer deaths in 2008 [1]. The past decades have seen advances in the diagnosis and treatment of breast cancer, associated with a decrease of mortality rate, although the changes vary widely between countries $[2,3]$. Among treatments, adjuvant radiotherapy has shown to improve local control and overall survival, with a $70 \%$ proportional reduction of the risk of recurrence [4] and a $9 \%-12 \%$ proportional reduction of the risk of death [5-8]. Despite this established role of radiotherapy, there are considerable disparities in the receipt of radiotherapy that are attributable to various factors such as limited availability of treatment centers, geographical distance, long waiting times, and costs [9-11]. The disparities can further be compounded by the long schedules required with conventional radiotherapy, since the schedules of radiotherapy that were evaluated in clinical trials and were found to be associated with improved survival are based on conventional fractionation of 1.8$2.5 \mathrm{~Gy} /$ fraction, delivering treatment over 5 to 7 weeks $[5,8,12,13]$. Many researches are actively investigating alternative approaches. Intraoperative radiotherapy (IORT) $[14,15]$ or accelerated partial breast irradiation (APBI) [16] provide the shortest schedules. However, IORT and APBI are limited to selected cases of breast conservation therapy [17]. Whole breast radiotherapy with a hypofractionated schedule delivering 42.5 Gy in 16 fractions over 22 days has been shown by the Ontario randomized trial to be comparable with a conventional schedule of $50 \mathrm{~Gy}$ in 25 fractions over 35 days [18]. However, boost radiation was not used. The UK START trial A and trial B found that $41.6 \mathrm{~Gy}$ in 13 fractions over 5 weeks or $40 \mathrm{~Gy}$ in 15 fractions over 3 weeks given after breast conserving surgery (BCS) or after mastectomy (MA) had outcomes on local control and adverse effects comparable to the conventional treatment of 50 Gy in 25 fractions over 5 weeks $[19,20]$. A boost of 10 Gy in 5 fractions was allowed to centers that elected to give boost, as well as regional radiotherapy to supraclavicular nodes with or without axillary chains. The issue of boost radiation was not addressed in the Ontario trial, for this reason boost was given by conventional fractionation in the UK START trials, reducing the gain in scheduling time.

In the present study, we designed an experimental hypofractionated schedule that would shorten overall treatment time and be applicable to mastectomy patients as well as to breast conservation patients by integrating a simultaneous boost. The experimental treatment is compared with conventional radiotherapy in a randomized clinical trial (NCT00459628). The present study reports early toxicities.

\section{Methods}

The primary outcome measure defined in the trial was the change from baseline in pulmonary and heart function tests up to 3 years after treatment. The secondary outcome measures were local-regional recurrences. The trial started recruiting patients in May 2007. Eligible patients were women aged 18 years or older, presenting with histologically proven breast carcinoma, operated by BCS or MA with clear margins, pathological stage T13N0M0 or T1-2N1M0 [21]. Availability of at least one pre-operative imaging by CT, MRI, and/or PET-scan was required. Exclusion criteria were history of prior breast or thoracic radiotherapy, pregnancy or lactation, absence of effective contraception in fertile patients, psychiatric or addictive disorders.

After written informed consent, patients were randomized to either a control arm of conventional radiotherapy (CR), or to the experimental arm of hypofractionated Tomotherapy (TT). Randomization was balanced by nodal status, type of surgery and chemotherapy sequence using Efron's biased coin design [22].

In the control arm, a dose of 50 Gy was delivered in 25 fractions over 5 weeks to the chest wall (MA) or the whole breast (BCS) by 6 or $15 \mathrm{MV}$ photons tangential wedged fields and using field-in-field multileaf compensation when doses exceed $110 \%$, and to the supraclavicular, infraclavicular and axillary nodes in case of pN1 status, using an anterior $6 \mathrm{MV}$ photons half-beam matched to the superior border of the tangential fields. The field borders were set clinically. The typical tangential field borders were: superior just below the clavicle head, inferior $1.5 \mathrm{~cm}$ below the infra-mammary crease or the lower part of the ipsilateral breast (BCS) or the contralateral breast (MA), medial at mid-sternum and lateral at the mid-axillary line (pN0) or at the anterior border of the scalene muscles (pN1). The borders of the supraclavicular field were: superior caudal to the cricoid cartilage, inferior at the caudal edge of the clavicle head, medial excluding the trachea and lateral at the junction of the first rib with the clavicle. Breast conserved patients received an additional boost of 16 Gy in 8 fractions over 2 weeks to the initial tumor bed using a direct electron field, i.e. a cumulative dose of 66 Gy in 33 fractions over 7 weeks at the tumor bed. No dose constraints for lung and heart were defined in the conventional arm, but the perpendicular distance from the chest wall to the posterior field edge preferably included no more than $2 \mathrm{~cm}$ of lung at any point along the length of the tangent. This lung distance was not to exceed $3 \mathrm{~cm}$. For left-sided breast radiotherapy, the maximum heart distance was not to exceed $1.5 \mathrm{~cm}$. The boost volume was aligned taking into account the preoperative imaging (mammography and CT, MRI or PET) and post-operative changes (scar, seroma) seen on the 
planning-CT. A clinical target volume (CTV) -margin of $7 \mathrm{~mm}$ was used. Often surgical clips at the borders of the operation area were available. These clips were to be inside the CTV. CTV to planning target volume (PTV) margin was $5 \mathrm{~mm}$.

In the experimental arm, patients were treated using the Helical TomoTherapy ${ }^{\circledR} \mathrm{Hi}$-art system [23] (Madison, US). A total dose of 42 Gy in 15 fractions over 3 weeks was prescribed to the same target volumes as the conventional arm: chest wall in case of MA or whole breast in case of BCS, and to the supraclavicular, infraclavicular and axillary nodes in case of pN1 status. In case of BCS, a simultaneous integrated boost (SIB) of 0.6 Gy per fraction was prescribed to the tumor bed, i.e. a dose of 51 Gy in 15 fractions over 3 weeks at the tumor bed. The boost volume was aligned as for the conventional radiotherapy, with the same CTV and PTV margins. Tomotherapy dose specifications for target volumes breast/chest wall, boost, and lymph node regions were to receive $95 \%-105 \%$ of prescribed dose. Dose constraints for heart and ipsilateral lung were respectively $\mathrm{V} 5 \mathrm{~Gy}<10 \%$ and $\mathrm{V} 17 \mathrm{~Gy}<7 \%$, contralateral breast V10Gy $<5 \%$.

Per protocol, radiotherapy in any arm started within 6 weeks after breast surgery. In case of sequential adjuvant treatment with chemotherapy first, radiotherapy started after a delay of 2 weeks, but within 6 weeks after completion of adjuvant chemotherapy. Concomitant chemotherapy was allowed.

Pulmonary and heart function, arm mobility and arm lymphedema were assessed prior to radiotherapy, at $2( \pm$ 1) months after completion of radiotherapy and thereafter yearly for 3 years. Heart function was assessed by measuring the left ventricular ejection fraction (LVEF) by echocardiography. Pulmonary function tests assessed forced expiratory volume in one second (FEV1) and diffusing capacity of the lung for carbon monoxide (DLco). Heart and lung toxicity scoring was based on the common terminology criteria of adverse events (CTCAE) v.3 [24]. Scoring of breast/chest wall skin and subcutaneous toxicity used the Radiation Therapy Oncology Group (RTOG) acute (up to 1 month post radiotherapy) and late (after 1 month) morbidity scoring schemas [25]. Scoring of arm lymphedema used the SOMA/LENT toxicity scale [26].

The planned accrual was to recruit 118 patients, based on a power of 0.80 to detect a $5 \%$ vs. $25 \%$ incidence of all heart and lung toxicities between the two treatment arms. The trial closed for inclusion in August 2011. A total of 123 patients were randomized after giving informed consent. The present report concerns the first 70 patients enrolled up to August 2009, having a minimal follow-up time of 1 year. The follow-up cut-off date was May 2011. Data were analyzed by intention to treat.
Comparison of proportions used Fisher's exact test, onesided. Statistical computations used JMP v. 8.0.1 (SAS Institute Inc, Cary, NC, USA). The trial was accepted by the ethical committee of the UZ Brussel.

\section{Results}

Of the 70 women with more than 1 year follow-up, 1 patient was not eligible due to bilateral breast carcinoma, leaving 69 patients available for the present study. Thirty two were randomized to CR, 37 to TT. Two patients allocated to $\mathrm{CR}$ refused conventional treatment and were subsequently treated by TT. One patient allocated to TT could not be positioned on the Tomotherapy couch because of extreme obesity, she was treated by CR.

The mean age of the study participants was 55 years (range 32--78 years) (Table 1). There was a nonsignificant preponderance of left sided tumors, 58\% (40 of 69). A medial tumor location was observed in $29 \%$ (20 of 69) patients. Breast conserving surgery was performed in 59\% (41 of 69) patients. Axillary surgery was by sentinel nodes biopsy alone in 54\% (37 of 69), sentinel nodes biopsy followed by completion axillary lymph node dissection in 14\% (10 of 69), and axillary lymph node dissection by first intent in 32\% (22 of 69). The pathological mean tumor size was $17 \mathrm{~mm}$ (range 2-$42 \mathrm{~mm}$ ). Multifocality was noted in $14 \%$ (10 of 69) patients. The majority of patients were node negative, $65 \%$ (45 of 69). The mean lymph node ratio (LNR) among node-positive patients was 0.13 (range 0.040.33). Using cut-offs of 0.20 and 0.65 [27], 79\% (19 of 24) of the node-positive patients had a low LNR, $21 \%$ (5 of 24) had an intermediary LNR, and no patient had a high LNR. The frequencies of estrogen receptor positivity, progesterone receptor positivity, and HER2 FISH amplification were $80 \%$ (55 of 69), 67\% (46 of 69), and $14 \%$ (10 of 69 ), respectively. A high histological grade was observed in 26\% (18 of 69) patients. Adjuvant chemotherapy was given to $49 \%$ (34 of 69) patients. Among patients receiving adjuvant chemotherapy, most had chemotherapy scheduled to start concomitantly with radiotherapy, $76 \%$ ( 26 of 34 ), i.e. $38 \%$ of all patients. Adjuvant hormone therapy was given to $80 \%$ ( 55 of 69 ) and trastuzumab to $14 \%$ (10 of 69 ) patients.

The distribution of the patients' characteristics by age, laterality, tumor location, type of surgery, histopathology, hormone receptor status, tumor size, lymph node positivity and ratio, adjuvant chemotherapy and hormone therapy were comparable between the two randomization arms (Table 1).

Figure 1 shows the average dose volume histograms (DVH) for the breast/chest wall (CTV1), the lymph node areas (CTVn), the contralateral breast, the ipsilateral lung for all patients and the heart for left sided irradiation. This shows a more homogeneous coverage of the CTV1 and 
Table 1 Patients' characteristics

\begin{tabular}{|c|c|c|}
\hline & $\begin{array}{c}\text { Control } \\
n=32\end{array}$ & $\begin{array}{c}\text { Tomotherapy } \\
n=37\end{array}$ \\
\hline \multicolumn{3}{|l|}{ Age } \\
\hline$<50$ & 10 & 15 \\
\hline$>=50$ & 22 & 22 \\
\hline Left breast tumor & 16 & 24 \\
\hline Medial location & 12 & 8 \\
\hline \multicolumn{3}{|l|}{ Tumor size } \\
\hline $\mathrm{T} 1(<=20 \mathrm{~mm})$ & 21 & 26 \\
\hline $\mathrm{T} 2(21-50 \mathrm{~mm})$ & 11 & 11 \\
\hline \multicolumn{3}{|l|}{ Nodal status, Lymph node ratio } \\
\hline pNO & 21 & 24 \\
\hline pN1, LNR 0.01-0.20 & 7 & 12 \\
\hline pN1, LNR 0.21-0.65 & 4 & 1 \\
\hline $\mathrm{pN1}, \mathrm{LNR}>0.65$ & 0 & 0 \\
\hline Estrogen receptor positive & 28 & 27 \\
\hline Progesterone receptor positive & 21 & 25 \\
\hline HER2 FISH amplified & 2 & 8 \\
\hline \multicolumn{3}{|l|}{ Histological grade } \\
\hline 1 & 11 & 11 \\
\hline 2 & 8 & 18 \\
\hline 3 & 10 & 8 \\
\hline unknown & 3 & 0 \\
\hline \multicolumn{3}{|l|}{ Surgery } \\
\hline Breast conserving & 21 & 20 \\
\hline \multicolumn{3}{|l|}{ Axillary lymph nodes } \\
\hline Sentinel biopsy only & 20 & 17 \\
\hline Sentinel with axillary dissection & 4 & 6 \\
\hline Immediate axillary dissection & 8 & 14 \\
\hline \multicolumn{3}{|l|}{ Radio-chemotherapy schedule } \\
\hline No adjuvant chemotherapy & 18 & 17 \\
\hline RT after completion of chemotherapy & 3 & 5 \\
\hline RT concomitant with start chemotherapy & 11 & 15 \\
\hline \multicolumn{3}{|l|}{ Chemotherapy type } \\
\hline Anthracycline without taxane & 3 & 4 \\
\hline Anthracycline with taxane & 10 & 15 \\
\hline CMF & 1 & 1 \\
\hline \multicolumn{3}{|l|}{ Hormone therapy } \\
\hline No hormone therapy & 4 & 10 \\
\hline Tamoxifen & 15 & 11 \\
\hline Letrozole & 13 & 11 \\
\hline Zoladex & 0 & 1 \\
\hline Tamoxifen + Zoladex & 0 & 4 \\
\hline Trastuzumab & 2 & 8 \\
\hline
\end{tabular}

the CTVn in the Tomotherapy group. We compare the CTV and not the PTV data, because no PTV is made for the conventional treatment, since the borders of the irradiation field for this group are chosen according to clinical landmarks. A small margin is allowed in the Tomotherapy group, since daily megavolt CT imaging is performed before every treatment session. Notice the tail in the CTV1 of the Tomotherapy group. This is explained by the dose gradient from the CTV1 to the boost volume $(\mathrm{CTVb})$. This is not present in the conventional therapy, because the boost in this group is given after the end of the whole breast irradiation. This additional boost is given with electrons. Our planning system does not allow a dose calculation for electrons. This means that the DVHs for the conventional therapy lack part of the actual received dose. Even so there is fewer dose to the heart and ipsilateral lung with Tomotherapy. The average dose on the heart is 7.1 Gy $\pm 5.7 \mathrm{~Gy}(\mathrm{CR}), 1.7 \mathrm{~Gy} \pm 2.5 \mathrm{~Gy}(\mathrm{TT})$, on the ipsilateral lung is $6.6 \mathrm{~Gy} \pm 12.0 \mathrm{~Gy}(\mathrm{CR})$ and $4.7 \mathrm{~Gy} \pm 7.5 \mathrm{~Gy}(\mathrm{TT})$. A higher dose is delivered on the contralateral breast with Tomotherapy compared to the conventional treatment (average dose CR: $0.3 \mathrm{~Gy} \pm 0.5$ Gy vs. TT: $2.6 \mathrm{~Gy} \pm 2.3 \mathrm{~Gy}$ ). These findings are in line with the results of a planning study we performed earlier [23].

The median follow-up of all patients was 28 months (range 16--48 months). No patient died during follow-up. There was no local recurrence or new primary breast tumor. One patient in the control arm was diagnosed with bone metastases 2 months after randomization. A second primary tumor was diagnosed in 3 patients in the control arm (1 skin basal cell carcinoma of the nose, 1 kidney carcinoma, 1 sigmoid carcinoma) and in 1 patient in the Tomotherapy arm (1 lung adenocarcinoma) $(\mathrm{P}=0.3)$.

All patients completed radiotherapy. Mean treatment duration was 43 days (range 20--54) in the conventional arm, 22 days (range 18--36) in the Tomotherapy arm. At completion and up to 1 month after radiotherapy, the clinical evaluation and RTOG acute scoring found skin toxicity grade 0 in $6.25 \%$ ( 2 of 32 ), grade 1 in $65.6 \%$ (21 of 32 ), grade 2 in $21.9 \%$ (7 of 32), and grade 3 in $6.25 \%$ ( 2 of 32) of patients in the control arm; grade 0 in $5.4 \%$ (2 of 37), grade 1 in $59.5 \%$ (22 of 37), grade 2 in $27.0 \%$ (10 of 37), grade 3 in $8.1 \%(3$ of 37$)$ in the Tomotherapy arm ( $\mathrm{P}$ Chi-square $=$ 0.94). Peak erythema occurred at the end of treatment in the conventional arm and at 10 to 14 days after end of treatment in the Tomotherapy arm.

Table 2 summarizes toxicities observed from 2 months up to 2 years. We pooled all toxicities of grade 1 or higher as compared with pre-radiotherapy baseline. At 2 years, patients in $\mathrm{CR}$ had twice more persistent skin change than patients in the TT, $60 \%$ (12 of 20 patients) vs. $30 \%$ ( 6 of 20 patients), $P=0.06$. The frequencies of breast/chest wall fibrosis, arm lymphedema and heart toxicity (LVEF) were comparable between the two randomization arms. Lung function tests showed a significant reduction of lung toxicity in TT based on changes of DLco, $\mathrm{P}=0.047$, but not based on changes of FEV1. Figure 2 shows the individual DVHs for the 


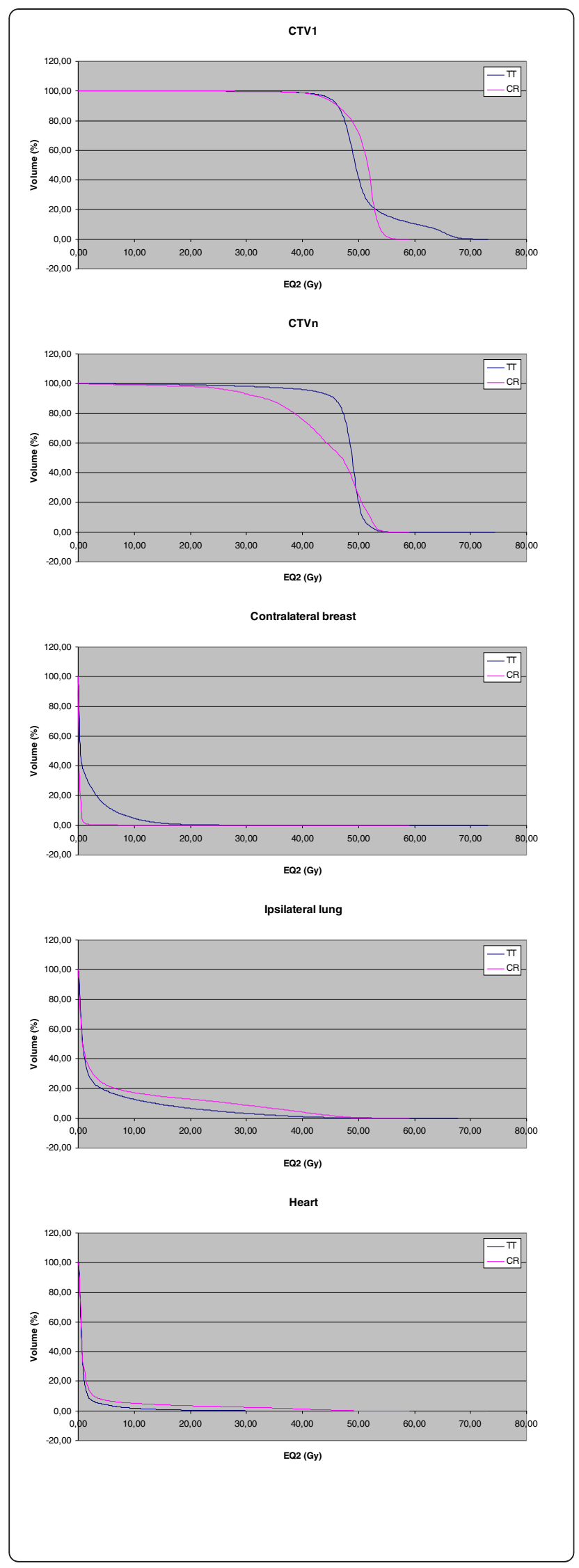

Figure 1 Dose volume histogram. The average dose volume histograms (DVH) of the CTV's and the most important organs at risk are shown for $\mathrm{CR}$ and $\mathrm{T}$. The average DVH for the heart was generated for left sided irradiation only. The dose is formulated in 2 Gy equivalent dose (EQ2) with an alpha/beta of $3 \mathrm{~Gy}$.

patients who had G1 or higher lung toxicity based on DLco, which showed consistent over time, compared to the average DVH. The individual DVHs are positioned above, as well as below the average DVH. In the situation that the observed lung toxicity would be closely related to the delivered lung dose, one would expect all the individual DVHs above the average DVH. Among these 9 women 7 were treated with concomitant chemotherapy, of which 3 were irradiated on the lymph node regions. A boost dose was delivered in 4 women. Three women had a smoking history. One woman had known asthma.

\section{Discussion}

A meta-analysis performed in our department, using data of the Early Breast Cancer Trialists' Cooperative Group (EBCTCG), argued that trials showing a survival benefit were the more recent trials using current techniques [5]. Considering that the survival advantage with adjuvant radiotherapy was confirmed $[6,28]$, the question that arises is whether or not breast cancer could further benefit from more advanced radiotherapy techniques. There are however two obstacles against the implementation of image guided radiotherapy (IGRT) for breast cancer patients. One obstacle is that IGRT is labor intensive. Priority to implement IGRT is given to the treatment of tumor conditions in which adverse reactions can be severe and debilitating, such as lung cancer, digestive or head and neck tumors $[29,30]$. The other obstacle is the controversy on whether IGRT could improve over simpler variants of tangential fields [31]. There is thus a need to prospectively assess the benefit of IGRT for breast cancer patients.

The earlier mentioned meta-analysis also argued that a survival benefit was shown in trials using a standard fractionation between 1.8 Gy and 2.5 Gy per fraction [5]. Since then, there has been growing evidence on the applicability of hypofractionation for adjuvant radiotherapy of breast cancer, as shown in Table 3. A natural extension is therefore to combine hypofractionation with IGRT in order to improve the availability of IGRT to breast cancer patients. Our clinical trial is the first to compare an integrated strategy of hypofractionated IGRT, versus a strategy of conventional radiotherapy.

Our choice of fractionation of 42 Gy to whole breast and boost to $51 \mathrm{~Gy}$ in 15 fractions took into account that our institution's standard conventional radiotherapy is 50 Gy to whole breast and boost to $66 \mathrm{~Gy}$. In the IMPACT HIGH trial, the schedule in 15 fractions is to deliver 36 Gy to 
Table 2 Occurrence of toxicity grade $\geq 1$ change from baseline after radiation treatment, by intent to treat randomization arm

\begin{tabular}{|c|c|c|c|c|c|c|}
\hline \multicolumn{3}{|c|}{ Control } & \multicolumn{3}{|c|}{ Tomotherapy } & \multirow[b]{2}{*}{$\begin{array}{c}\text { P-value } 1 \\
\text { sided }\end{array}$} \\
\hline $\begin{array}{l}\text { Number of } \\
\text { patients } \\
\text { evaluated }\end{array}$ & $\begin{array}{l}\text { Observed } \\
\text { grade } \geq 1\end{array}$ & $\begin{array}{c}\% \\
\text { grade } \\
\geq 1\end{array}$ & $\begin{array}{c}\text { Number of } \\
\text { patients } \\
\text { evaluated }\end{array}$ & $\begin{array}{l}\text { Observed } \\
\text { grade } \geq 1\end{array}$ & $\begin{array}{c}\% \\
\text { grade } \\
\geq 1\end{array}$ & \\
\hline
\end{tabular}

\section{Skin}

$\begin{array}{ll}\text { at } 2 \text { months } & 32 \\ \text { at } 1 \text { year } & 31 \\ \text { at } 2 \text { years } & 20\end{array}$

\section{Breast/chest wall fibrosis}

$\begin{array}{ll}\text { at } 1 \text { year } & 32 \\ \text { at } 2 \text { years } & 24\end{array}$

32
24

$\geq 1$

evaluated

$\geq 1$

\section{Arm lymphedema}

$\begin{array}{ll}\text { at } 2 \text { months } & 32 \\ \text { at } 1 \text { year } & 32 \\ \text { at } 2 \text { years } & 24\end{array}$

$32-2$

\section{Heart function}

$\begin{array}{ll}\text { at } 2 \text { months } & 32 \\ \text { at } 1 \text { year } & 31 \\ \text { at } 2 \text { years } & 21\end{array}$

$\begin{array}{ccc}65.6 & 21 & 36 \\ 14 & 45.2 & 36 \\ 12 & 60.0 & 20\end{array}$

$\begin{array}{lll}24 & 66.7 & 0.636 \\ 14 & 38.9 & 0.393 \\ 6 & 30.0 & 0.056\end{array}$

Lung toxicity score based on change in FEV1 (*)

$\begin{array}{ll}\text { at } 2 \text { months } & 30 \\ \text { at } 1 \text { year } & 29 \\ \text { at } 2 \text { years } & 24\end{array}$

$\begin{array}{ll}4 & 13.3 \\ 4 & 13.8 \\ 5 & 20.8\end{array}$

Lung toxicity score based on change in DLco $\left.{ }^{*}\right)$

$\begin{array}{llll}\text { at } 2 \text { months } & 30 & 10 & 33.3 \\ \text { at } 1 \text { year } & 29 & 8 & 27.6 \\ \text { at } 2 \text { years } & 24 & 7 & 29.2\end{array}$

Lung toxicity based on change in FEV1 and DLco $(*)$

\begin{tabular}{llllllll} 
at 2 months & 30 & 12 & 40.0 & 34 & 10 & 34.3 & 0.266 \\
at 1 year & 29 & 12 & 41.4 & 34 & 6 & 28.6 & 0.036 \\
at 2 years & 24 & 10 & 41.7 & 27 & 5 & 22.2 & 0.066 \\
\hline
\end{tabular}

$(*)$ Cases who did not receive RT according to randomization arm were computed as missing.

whole breast, and simultaneous integrated boost to $48 \mathrm{~Gy}$ $53 \mathrm{~Gy}$, which based on an alpha/beta of 3 Gy would correspond to conventional schedule of 40 Gy whole breast and boost to 60 Gy - 69 Gy [38].

Table 3 shows how our study compares with other clinical trials. We are aware of several controversial issues, notably regarding post-mastectomy radiotherapy for node-negative patients and for node-positive patients with less than 4 nodes involved. We have argued that these patients did derive a survival benefit $[39,40]$ and have maintained the treatment of nodal areas in node-positive patients regardless of the number of involved nodes. Most recently, results from the MA 20 trial confirmed that regional nodal irradiation prolonged disease free survival for women with one to three involved nodes [41].
Another controversial issue is the high number of patients treated by concomitant chemo-radiotherapy. One randomized trial found a significantly better loco regional recurrence free survival with a concomitant approach in node-positive breast cancer, with an acceptable increase in toxicity $[42,43]$. More data with current chemotherapy regimens, including taxanes, will need to be accrued.

There is the issue of delivering a simultaneous integrated boost, giving an even higher daily dose to the tumor bed. We could show this did not deliver a higher dose to the organs at risk. This technique could prove advantageous by even delivering less total dose to the surrounding breast tissue [44], though this was not analyzed in detail. Longer follow up is needed to compare the long term side effects. 
Ipsilateral lung TT

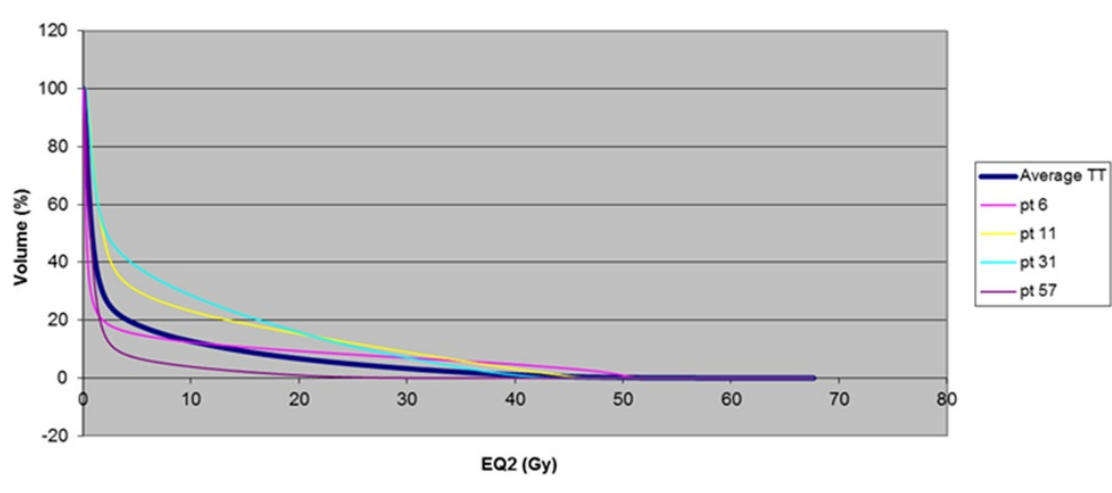

Ipsilateral lung $\mathbf{C R}$

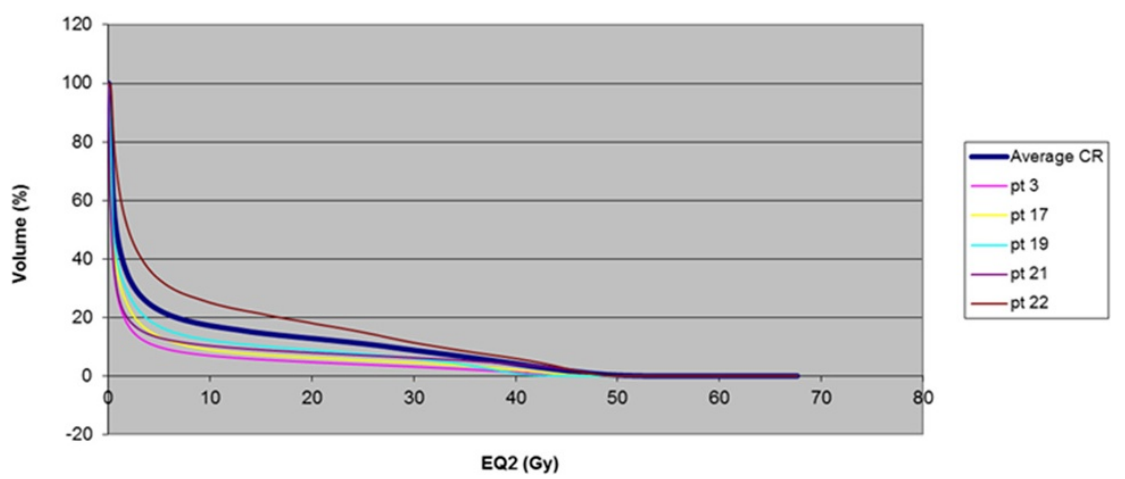

\begin{tabular}{|c|c|c|c|c|c|}
\hline Patient nr & Boost dose & $\begin{array}{c}\text { Lymph node } \\
\text { irradiation }\end{array}$ & $\begin{array}{c}\text { Adjuvant } \\
\text { chemotherapy }\end{array}$ & $\begin{array}{c}\text { Smoking } \\
\text { (pack year) }\end{array}$ & Asthma \\
\hline 6 & - & - & + & - & - \\
\hline 11 & - & + & + & + & $(5)$ \\
\hline 31 & - & + & + & - & - \\
\hline 57 & + & - & + & $\begin{array}{c}\text { stopped } \\
(30)\end{array}$ & - \\
\hline 3 & - & - & - & - & - \\
\hline 17 & + & - & - & - & + \\
\hline 19 & + & - & + & stopped \\
$(5)$ & - \\
\hline 21 & - & - & + & - & - \\
\hline
\end{tabular}

Figure 2 DVHs of the ipsilateral lung for patients who showed consistent DLco-decrease of $>10 \%$. The individual DVHs for the patients who had G1 or higher lung toxicity based on DLCo, which proved consistent over time, are shown compared to the average DVH for $\Pi T$ and CR. The dose is formulated in 2 Gy equivalent dose (EQ2) with an alpha/beta of 3 Gy.

The trial compares two treatment strategies. Differences that arise between the treatment arms cannot be unequivocally attributed to fractionation or to technique. A 2x2 design would have been conceptually more satisfying, but was practically unfeasible.

Regarding the trial's primary endpoint, the results showed a trend of reduced lung toxicities but not significant enough to warrant early stopping of the trial. No excess toxicities were found in the Tomotherapy arm, which argues that hypofractionation with simultaneous integrated boost is feasible, when using IMRT-IGRT. This can have important implication regarding availability and accessibility of advanced radiotherapy techniques to more patients. Hypofractionation not only is more convenient for the patients by limiting the number of treatment attendances, it can reduce waiting times for adjuvant radiation therapy and possibly impact on survival [45]. Shorter schedules can have an important socio-economic impact by lowering 
Table 3 Randomized clinical trials of hypofractionated whole breast/chest wall radiotherapy

\begin{tabular}{|c|c|c|c|c|c|c|c|c|c|}
\hline Trial & Period & $\mathrm{n}$ & $\begin{array}{l}\text { Hypofraction } \\
\text { schedule }\end{array}$ & SIB & Mastectomy & $\begin{array}{l}\text { Regional } \\
\text { nodes }\end{array}$ & $\begin{array}{l}\text { IMRT/ } \\
\text { IGRT }\end{array}$ & $\begin{array}{l}\text { Chemo- } \\
\text { therapy }\end{array}$ & Outcome \\
\hline \multirow{2}{*}{$\begin{array}{l}\text { Hôpital } \\
\text { Necker } \\
(*)[32]\end{array}$} & $1982-$ & \multirow[t]{2}{*}{230} & 5.75 Gy x 4 F/ 17 & \multirow[t]{2}{*}{ No } & \multirow[t]{2}{*}{ Yes } & \multirow[t]{2}{*}{$?$} & \multirow[t]{2}{*}{ NS } & \multirow[t]{2}{*}{ Yes } & \multirow[t]{2}{*}{$=$} \\
\hline & 1984 & & days & & & & & & \\
\hline \multirow{2}{*}{$\begin{array}{l}\text { Royal } \\
\text { Marsden } \\
\text { Hospital [33] }\end{array}$} & 1986- & \multirow[t]{4}{*}{1410} & 3 Gy $\times 13$ F/ 5 & \multirow[t]{2}{*}{ No } & \multirow[t]{2}{*}{ No } & \multirow[t]{2}{*}{ Yes } & \multirow[t]{2}{*}{ NS } & \multirow[t]{2}{*}{ No } & \multirow{2}{*}{$\begin{array}{l}\text { More local } \\
\text { relapses }\end{array}$} \\
\hline & 1998 & & weeks & & & & & & \\
\hline \multirow{2}{*}{\multicolumn{2}{|c|}{$\begin{array}{l}\text { Royal } \\
\text { Marsden } \\
\text { Hospital }\end{array}$}} & & 3.3 Gy x 13 F/ 5 & No & No & Yes & NS & No & $=$ \\
\hline & & & weeks & & & & & & \\
\hline \multirow[t]{2}{*}{ Ontario [18] } & 1993- & \multirow[t]{2}{*}{1234} & 2.66 Gy x 16 F/ 3 & \multirow[t]{2}{*}{ No } & \multirow[t]{2}{*}{ No } & \multirow[t]{2}{*}{ No } & \multirow[t]{2}{*}{ NS } & \multirow[t]{2}{*}{ Yes } & \multirow[t]{2}{*}{$=$} \\
\hline & 1996 & & weeks & & & & & & \\
\hline \multirow{2}{*}{$\begin{array}{l}\text { UK Start } \\
\text { A [19] }\end{array}$} & 1998- & \multirow[t]{2}{*}{2236} & $3 \mathrm{~Gy} \times 13 \mathrm{~F} / 5$ & No & Yes & Yes & NS & Yes & More local \\
\hline & 2002 & & weeks & & & & & & \\
\hline UK Start A & & & $3.2 \mathrm{~Gy} \times 13 \mathrm{~F} / 5$ & No & Yes & Yes & NS & Yes & $=$ \\
\hline & & & weeks & & & & & & \\
\hline Lahore [34] & 1998- & 300 & $5.4 \mathrm{~Gy} \times 5$ F/ 1 & No & Yes & Yes & NS & Yes & $=$ \\
\hline & 2004 & & week & & & & & & \\
\hline Lahore & & & $3.5 \mathrm{~Gy} \times 10$ F/ 2 & No & Yes & Yes & NS & Yes & $=$ \\
\hline & & & weeks & & & & & & \\
\hline Lahore & & & $2.66 \mathrm{~Gy} \times 15$ F/ 3 & No & Yes & Yes & NS & Yes & Control arm \\
\hline & & & weeks & & & & & & \\
\hline UK Start B [20] & 1999- & 2215 & 2.67 Gy x 15 F/ 3 & No & Yes & Yes & NS & Yes & $=$ \\
\hline & 2001 & & weeks & & & & & & \\
\hline Egypt NCl [35] & $2002-$ & 30 & 2.66 Gy x 16 F/ 3 & No & No & No & NS & No & Boost in \\
\hline & 2003 & & weeks & & & & & & con \\
\hline UK FAST [36] & $2004-$ & 915 & $5.7 \mathrm{~Gy} \times 5$ F/ 5 & $?$ & No & No & Yes & No & $=$ \\
\hline & 2007 & & weeks & & & & & & \\
\hline UK FAST & & & $6 \mathrm{~Gy} \times 5$ F/ 5 & $?$ & No & No & Yes & No & More breast \\
\hline & & & weeks & & & & & & toxicity \\
\hline DBCG 2009 & 2009- & $1500^{* *}$ & $2.67 \mathrm{~Gy} \times 15$ F/ 3 & No & No & No & Yes & Yes & On-going \\
\hline & & & weeks & & & & & & \\
\hline UK IMPORT & 2009- & $840^{* *}$ & 2.4 Gy [SIB 3.2 Gy] & Yes & No & $?$ & Yes & $?$ & On-going \\
\hline & & & $\times 15 \mathrm{~F} /$ & & & & & & \\
\hline $\begin{array}{l}\text { UK IMPORT } \\
\text { HIGH }\end{array}$ & & & $\begin{array}{c}2.4 \text { Gy [SIB } 3.53 \\
\text { Gy] }\end{array}$ & Yes & No & $?$ & Yes & $?$ & \\
\hline & & & $\times 15 \mathrm{~F} /$ & & & & & & \\
\hline UZ Brussel & 2007- & 122 & 2.8 Gy [SIB 3.4 Gy] & Yes & Yes & Yes & Yes & Yes & Closed for \\
\hline [this study] & & & x 15 F/ 3 weeks & & & & & & $\begin{array}{l}\text { Inclusion; FU } \\
\text { on-going }\end{array}$ \\
\hline
\end{tabular}

(*) Partial report; full study $1982-1989, \mathrm{n}=525$ patients. $\left.{ }^{* *}\right)$ Planned accrual.

NS: not stated. =: outcome comparable with control arm. SIB: simultaneous integrated boost. FU: follow-up.

treatment costs due to reduced resource use in terms of personnel and machine time [46]. An increase in costs can be expected due to the more labor intensive preparation of a Tomotherapy treatment and a longer daily machine time for treatment delivery and related quality assurance. But the most important determinant of the cost of radiotherapy is the total number of fractions. A favorable balance can be expected for the hypofractionated schedule.

\section{Conclusions}

The present analysis shows that hypofractionation with simultaneous integrated boost is feasible, when using 
IMRT-IGRT, without excess toxicities. There is a trend of reduced lung toxicity in the hypofractionated arm.

\begin{abstract}
Abbreviations
APBI: Accelerated partial breast irradiation; BCS: Breast conserving surgery; CR: Conventional radiotherapy; CTCAE: Common terminology criteria of adverse events; CTV: Clinical target volume; DLco: Diffusing capacity of the lung for carbon monoxide; DVH: Dose volume histogram; EBCTCG: Early Breast Cancer Trialists' Cooperative Group; EQ2: 2 Gyequivalent dose; FEV1: Forced expiratory volume in one second; IGRT: Image guided radiation treatment; IMRT: Intensity modulated radiotherapy; IORT: Intraoperative radiotherapy; LNR: Lymph node ratio; LVEF: Left ventricular ejection fraction; MA: Mastectomy; PTV: Planning target volume; RTOG: Radiation Therapy Oncology Group; SIB: Simultaneous integrated boost; TT: Tomotherapy.
\end{abstract}

\section{Competing interest}

The department had a research agreement with TomoTherapy Inc., Madison, WI.

\section{Authors' contributions}

HVP drafted the manuscript, participated in the coordination of the study and had a substantial contribution to the acquisition of data. GM helped to draft the manuscript and has made a contribution to the acquisition of data. WH conceived of the study, participated in its design and coordination, performed the statistical analysis, has made a contribution to the acquisition of data and helped to draft the manuscript. SV performed the technical analysis of the lung function tests and helped to draft the manuscript. NA performed the physical assessment and helped to draft the manuscript. DK performed the technical analysis of the heart function tests. TR and KL performed the treatment planning and planning analysis and helped to draft the manuscript. DS participated in the coordination of the study, performed the lung function tests and helped to perform the technical analysis. SH participated in the design of the study and its coordination and helped to draft the manuscript. GVC, WV and GS participated in the design of the study and revised the manuscript. DV has revised the manuscript. MDR has helped in drafting the manuscript and revised it. All authors read and approved the final manuscript.

\section{Acknowledgements}

This research was funded by grant SCIE2006-30 from the Foundation against Cancer, foundation of public interest.

\section{Author details}

'Department of Radiotherapy, UZ Brussel, Laarbeeklaan 101, 1090 Brussels, Belgium. ${ }^{2}$ Department of Pneumology, UZ Brussel, Laarbeeklaan 101, 1090 Brussels, Belgium. ${ }^{3}$ Department of Physical Therapy, UZ Brussel, Laarbeeklaan 101, 1090 Brussels, Belgium. ${ }^{4}$ Department of Cardiology, UZ Brussel, Laarbeeklaan 101, 1090 Brussels, Belgium.

Received: 2 March 2012 Accepted: 13 May 2012

Published: 1 June 2012

\section{References}

1. Jemal A, Bray F, Center MM, Ferlay J, Ward E, Forman D: Global cancer statistics. CA Cancer J Clin 2011, 61:69-90.

2. Sant M, Francisci S, Capocaccia R, Capocaccia R, Verdecchia A, Allemani C, Berrino F: Time trends of breast cancer survival in Europe in relation to incidence and mortality. Int J Cancer 2006, 119:2417-2422.

3. Autier P, Boniol M, La VC, LaVecchia C, Vatten L, Gavin A, Héry C, Heanue M: Disparities in breast cancer mortality trends between 30 European countries: retrospective trend analysis of WHO mortality database. BMJ 2010, 341:c3620.

4. Nielsen HM, Overgaard M, Grau C, Jensen AR, Overgaard J: Study of failure pattern among high-risk breast cancer patients with or without postmastectomy radiotherapy in addition to adjuvant systemic therapy: long-term results from the Danish Breast Cancer Cooperative Group DBCG 82 b and c randomized studies. I Clin Oncol 2006, 24:2268-2275.

5. Van de Steene J, Soete G, Storme G: Adjuvant radiotherapy for breast cancer significantly improves overall survival: the missing link. Radiother Oncol 2000, 55:263-272.
6. Vinh-Hung V, Verschraegen C, The Breast Conserving Surgery Project: Breast-conserving surgery with or without radiotherapy: pooled-analysis for risks of ipsilateral breast tumor recurrence and mortality. J Natl Cancer Inst 2004, 96:115-121.

7. Taylor ME, Haffty BG, Rabinovitch R, Arthur DW, Halberg FE, Strom EA, White JR, Cobleigh MA, Edge SB: ACR appropriateness criteria on postmastectomy radiotherapy expert panel on radiation oncology-breast. Int J Radiat Oncol Biol Phys 2009, 73:997-1002.

8. Buchholz TA: Radiation therapy for early-stage breast cancer after breastconserving surgery. N Engl J Med 2009, 360:63-70.

9. Gold HT, Do HT, Dick AW: Correlates and effect of suboptimal radiotherapy in women with ductal carcinoma in situ or early invasive breast cancer. Cancer 2008, 113:3108-3115.

10. Jones AP, Haynes R, Sauerzapf V, Crawford SM, Zhao H, Forman D: Travel time to hospital and treatment for breast, colon, rectum, lung, ovary and prostate cancer. Eur J Cancer 2008, 44:992-999.

11. Gorey KM, Luginaah IN, Holowaty EJ, Fung KY, Hamm C: Wait times for surgical and adjuvant radiation treatment of breast cancer in Canada and the United States: greater socioeconomic inequity in America. Clin Invest Med 2009, 32:E239-E249.

12. Gebski V, Lagleva M, Keech A, Simes J, Langlands AO: Survival effects of postmastectomy adjuvant radiation therapy using biologically equivalent doses: a clinical perspective. J Natl Cancer Inst 2006, 98:26-38,

13. Kaufmann M, Morrow M, Von Minckwitz G, Harris JR: Locoregional treatment of primary breast cancer: consensus recommendations from an International Expert Panel. Cancer 2010, 116:1184-1191.

14. Veronesi U, Orecchia R, Luini A, Galimberti V, Zurrida S, Intra M, Veronesi P, Arnone P, Leonardi MC, Ciocca M, Lazzari R, Caldarella P, Rotmensz N, Sangalli C, Sances D, Maisonneuve P: Intraoperative radiotherapy during breast conserving surgery: a study on 1,822 cases treated with electrons. Breast Cancer Res Treat 2010, 124:141-151.

15. Vaidya JS, Joseph DJ, Tobias JS, Bulsara M, Wenz F, Saunders C, Alvarado M, Flyger HL, Massarut S, Eiermann W, Keshtgar M, Dewar J, Kraus-Tiefenbacher U, Sütterlin M, Esserman L, Holtveg HMR, Roncadin M, Pigorsch S, Metaxas M, Famzon M, Mathews A, Corica T, Williams NR, Baum M: Targeted intraoperative radiotherapy versus whole breast radiotherapy for breast cancer (TARGIT-A trial): an international, prospective, randomised, non-inferiority phase 3 trial. Lancet 2010, 376:91-102.

16. Beitsch PD, Shaitelman SF, Vicini FA: Accelerated partial breast irradiation. J Surg Oncol 2011, 103:362-368.

17. Smith BD, Arthur DW, Buchholz TA, Haffty BG, Hardenbergh PH, Julian TB, Marks LB, Todor DA, Vicini FA, Whelan TJ, White J, Wo JY, Harris JR: Accelerated partial breast irradiation consensus statement from the American Society for Radiation Oncology (ASTRO). Int J Radiat Oncol Biol Phys 2009, 74:987-1001.

18. Whelan TJ, Pignol JP, Levine MN, Julian JA, Mackenzie R, Parpia S, Shelley W, Grimard L, Bowen J, Lukka H, Perera F, Fyles A, Schneider K, Gulavita S, Freeman C: Long-term results of hypofractionated radiation therapy for breast cancer. N Engl J Med 2010, 362:513-520.

19. Agrawal RK, Aird EG, Barret JM, Barrett-Lee PJ, Bentzen SM, Bliss JM, Brown J, Dobbs HJ, Haviland JS, Hoskin PJ, Hopwood P, Laxton PA, Magee BJ, Mills J, Morgan DAL, Owen JR, Simmons S, Sumo G, Sydenham MA, Venables K, Yarnold JR: The UK Standardisation of Breast Radiotherapy (START) Trial A of radiotherapy hypofractionation for treatment of early breast cancer: a randomised trial. Lancet Oncol 2008, 9:331-341.

20. Agrawal RK, Aird EG, Barret JM, Barrett-Lee PJ, Bentzen SM, Bliss JM, Brown J, Dobbs HJ, Haviland JS, Hoskin PJ, Hopwood P, Laxton PA, Magee BJ, Mills J, Morgan DAL, Owen JR, Simmons S, Sumo G, Sydenham MA, Venables K, Yarnold JR: The UK Standardisation of Breast Radiotherapy (START) Trial B of radiotherapy hypofractionation for treatment of early breast cancer: a randomised trial. Lancet 2008, 371:1098-1107.

21. Greene FL, Page DL, Fleming ID, Fritz A, Balch CM, Haller DG, Morrow M: Breast. In AJCC Cancer Staging Handbook. 6th edition. Springer; 2002:221-240.

22. Efron B: Forcing a sequential experiment to be balanced. Biometrika 1971, 58:403-417.

23. Reynders T, Tournel K, De Coninck P, Heymann S, Vinh-Hung V, Van Parijs $H$, Duchateau M, Linthout N, Gevaert T, Verellen D, Storme G: Dosimetric assessment of static and helical Tomotherapy in the clinical implementation of breast cancer treatments. Radioth Oncol 2009, 93:71-9. 
24. Cancer Therapy Evaluation Program, Common Terminology Criteria for Adverse Events v3.0 (CTCAE) 2006., [http://ctep.cancer.gov/ protocolDevelopment/electronic_applications/docs/ctcaev3.pdf]

25. Cox JD, Stetz J, Pajak TF: Toxicity criteria of the Radiation Therapy Oncology Group (RTOG) and the European Organization for Research and Treatment of Cancer (EORTC). Int J Radiat Oncol Biol Phys 1995, 31:1341-1346.

26. No authors listed: LENT SOMA tables. Radiother Oncol 1995, 35:17-60.

27. Vinh-Hung V, Verkooijen HM, Fioretta G, Neyrooud-Caspar I, Rapiti E, Vlastos G, Deglise C, Usel M, Lutz JM, Bouchardy C: Lymph node ratio as an alternative to $\mathrm{pN}$ staging in node-positive breast cancer. $J$ Clin Oncol 2009, 27:1062-1068.

28. Clarke M, Collins R, Darby S, Davies C, Elphinstone P, Evans E, Godwin J, Gray R, Hicks C, James S, MacKinnon E, McGale P, McHugh T, Peto R, Taylor C, Wang Y, Early Breast Cancer Trialists' Collaborative Group (EBCTCG): Effects of radiotherapy and of differences in the extent of surgery for early breast cancer on local recurrence and 15-year survival, an overview of the randomised trials. Lancet 2005, 366:2087-2106.

29. Verellen D, De Ridder MD, Linthout N, Tournel K, Soete G, Storme G: Innovations in image-guided radiotherapy. Nat Rev Cancer 2007, 7: 949-960.

30. De Ridder M, Tournel K, Van Nieuwenhove $Y$, Engels B, Hoorens A, Everaert $H$, Op de Beeck B, Vinh-Hung V, De Grève J, Delvaux G, Verellen D, Storme G: Phase II study of preoperative helical tomotherapy for rectal cancer. Int J Radiat Oncol Biol Phys 2008, 70:728-734.

31. Caudell JJ, De Los Santos JF, Keene KS, Fiveash JB, Wang W, Carlisle JD, Popple R: A dosimetric comparison of electronic compensation, conventional intensity modulated radiotherapy, and tomotherapy in patients with early-stage carcinoma of the left breast. Int J Radiat Oncol Biol Phys 2007, 68:1505-1511.

32. Baillet F, Housset M, Maylin C, Boisserie G, Bettahar R, Delanian S, Sabib: The use of a specific hypofractionated radiation therapy regimen versus classical fractionation in the treatment of breast cancer: a randomized study of 230 patients. Int J Radiat Oncol Biol Phys 1990, 19:1131-1133.

33. Owen JR, Ashton A, Bliss JM, Homewood J, Harper C, Hanson J, Haviland J, Bentzen SM, Yarnold JR: Effect of radiotherapy fraction size on tumour control in patients with early-stage breast cancer after local tumour excision: long-term results of a randomised trial. Lancet Oncol 2006, 7:467-471.

34. Shahid A, Athar MA, Asghar S, Zubiari T, Murad S, Yunas N: Post mastectomy adjuvant radiotherapy in breast cancer: a comparison of three hypofractionated protocols. J Pak Med Assoc 2009, 59:282-287.

35. Taher AN, El-Baradie MM, Essa H, Zaki O, Ezzat S: Hypofractionation versus conventional fractionation radiotherapy after conservative treatment of breast cancer: early skin reactions and cosmetic results. J Egypt Natl Canc Inst 2004, 16:178-187.

36. FAST Trialists group, Agrawal RK, Alhasso A, Barrett-Lee PJ, Bliss JM, Bloomfield D, Bowen J, Brunt AM, Donovan E, Emson M, Goodman A, Harnett A, Haviland JS, Kaggwa R, Morden JP, Robinson A, Simmons S, Stewart A, Sydenham MA, Syndikus I, Tremlett J, Tsang Y, Wheatley D, Venables K, Yarnold JR: First results of the randomised UK FAST Trial of radiotherapy hypofractionation for treatment of early breast cancer (CRUKE/04/015). Radiother Oncol 2011, 100:93-100.

37. Early Breast Cancer Trialists' Collaborative Group (EBCTCG): DBCG 2009 RT Hypo Protokol, udgave 3.1.01/09/2011: Hypofraktioneret versus normofraktioneret helbrystbestråling til lymfeknude-negative brystkræftpatienter: et randomiseret fase II studium. [http://www.dbcg. $\mathrm{dk}]$

38. Yarnold J, Bentzen SM, Coles C, Haviland J: Hypofractionated whole-breast radiotherapy for women with early breast cancer: myths and realities. Int J Radiat Oncol Biol Phys 2011, 79:1-9.

39. Voordeckers M, Van de Steen J, Vinh-Hung V, Storme G: Adjuvant radiotherapy after mastectomy for $\mathrm{pT} 1-\mathrm{pT} 2$ node negative (pN0) breast cancer: is it worth the effort? Radiother Oncol 2003, 68:227-231.

40. Voordeckers M, Vinh-hung V, Lamote J, Bretz A, Storme G: Survival benefit with radiation therapy in node-positive breast carcinoma patients. Strahlenther Onkol 2009, 185:656-662.

41. Whelan TJ, Olivotto I, Ackerman I, et al: An intergroup trial of regional nodal irradiation in early breast cancer. Abstract LBA1003. J Clin Oncol 2011 2011, 29(Suppl)
42. Rouëssé J, de la Lande B, Bertheault-Cvitkovic F, Serin D, Graïc Y, Combe M, Leduc B, Lucas V, Demange L, Nguyen TD, Castéra D, Krzisch C, Villet R, Mouret-Fourme E, Garbay JR, the Centr René Huguenin Breast Cancer Group, Nogués C: A phase III randomized trial comparing adjuvant concomitant chemoradiotherapy versus standard adjuvant chemotherapy followed by radiotherapy in operable node-positive breast cancer: final results. Int J Radiat Oncol Biol Phys 2006, 64:1072-1080.

43. Toledano A, Azria D, Garaud P, Fourquet A, Serin D, Bosset JF, Miny-Buffet J, Favre A, Le Floch O, Calais G: Phase III trial of concurrent or sequential adjuvant chemoradiotherapy after conservative surgery for early-stage breast cancer: Final Results of the ARCOSEIN trial. J Clin Oncol 2007, 25:405-410.

44. Dogan N, King S, Enami B, Mohideen N, Mirkovic N, Leybovich LB, Sethi A: Assessment of different IMRT boost delivery methods on target coverage and normal-tissue sparing. Int J Radiat Oncol Biol Phys 2003, 57:1480-1491.

45. Chen Z, King W, Pearcey R, Kerba M, Mackillop WJ: The relationship between waiting time for radiotherapy and clinical outcomes: $\mathrm{A}$ systematic review of the literature. Radiother Oncol 2008, 87:3-16.

46. Lievens Y: Hypofractionated breast radiotherapy: Financial and economic consequences. The Breast 2010, 19:192-197.

\section{doi:10.1186/1748-717X-7-80}

Cite this article as: Van Parijs et al.: Short course radiotherapy with simultaneous integrated boost for stage I-II breast cancer, early toxicities of a randomized clinical trial. Radiation Oncology 2012 7:80.

\section{Submit your next manuscript to BioMed Central and take full advantage of:}

- Convenient online submission

- Thorough peer review

- No space constraints or color figure charges

- Immediate publication on acceptance

- Inclusion in PubMed, CAS, Scopus and Google Scholar

- Research which is freely available for redistribution 